\title{
Synthesis of Fluorescently Labeled Antibodies Using Non-Canonical Amino Acids in Eukaryotic Cell-Free Systems
}

\author{
Marlitt Stech, Nathanaël Rakotoarinoro, Tamara Teichmann, \\ Anne Zemella, Lena Thoring, and Stefan Kubick
}

\begin{abstract}
Cell-free protein synthesis (CFPS) enables the development of antibody conjugates, such as fluorophore conjugates and antibody-drug conjugates (ADCs), in a rapid and straightforward manner. In the first part, we describe the cell-free synthesis of antibodies containing fluorescent non-canonical amino acids (ncaa) by using pre-charged tRNA. In the second part, we describe the cell-free synthesis of antibodies containing ncaa by using an orthogonal system, followed by the site-specific conjugation of the fluorescent dye DyLight 650-phosphine. The expression of the antibodies containing ncaa was analyzed by SDS-PAGE, followed by autoradiography and the labeling by in-gel fluorescence. Two different fluorescently labeled antibodies could be generated.
\end{abstract}

Key words Cell-free protein synthesis, Antibody, Antibody conjugates, IgGl, Non-canonical amino acid, Conjugation

1 Introduction

\begin{abstract}
ADCs represent one of the most promising strategies in the pharmaceutical industry to treat solid and hematological cancers. Up to date, nine of them are already approved [1]. The concept of ADCs combines the effect of highly specific tumor-targeting immunotherapy with the concept of chemotherapy relying on highly cytotoxic drugs. ADCs are considered as a strategy to provide a better cytotoxicity to immunotherapy and a better specificity to chemotherapy. ADCs are composed of a monoclonal antibody conjugated to a cytotoxic drug by a linker. In the early stages of the development of ADCs, non-toxic fluorescent agents can be used to optimize the conjugation efficiency, to analyze the internalization efficiency, and to locate and quantify the antibody in vitro and ex vivo, prior to the conjugation to the cytotoxic agent.

While full-length Immunoglobulin $\mathrm{G}(\operatorname{IgG})$ is mainly produced in the mammalian system [2], such as Chinese Hamster Ovary
\end{abstract}


(CHO) cell lines, the drug is produced either by hemi-synthesis or by chemical synthesis. One strategy to conjugate the latter to the former is the amber suppression technology [3-6]. This technology is based on the introduction of an amber stop codon into the gene sequence at a desired position. By adding an engineered tRNA and synthetase the ncaa is incorporated in the antibody sequence during its synthesis exactly at the position of the amber stop codon. Following protein synthesis, the drug containing the corresponding reactive group can be conjugated to the antibody by the reactive group of the ncaa. The basis of the amber suppression technology is an orthogonal tRNA/synthetase pair. The orthogonal synthetase is engineered to amino-acylate specifically the ncaa at the $3^{\prime}$-end of the orthogonal tRNA. The latter is engineered to recognize the amber stop codon, thus allowing for the incorporation of the ncaa in a site-specific manner. Most importantly, the orthogonal tRNA/ synthetase pair should not show cross-reactivities between endogenous amino acids, tRNAs, and synthetases.

Orthogonal systems and the resulting products can be developed by using a CFPS system [5]. The CFPS system based on CHO lysate contains microsomes derived from the endoplasmic reticulum of CHO cells as previously described [7]. By translocating de novo synthesized proteins into the lumen of these microsomes by using a melittin signal peptide, post-translational modifications such as disulfide bridge formation and glycosylation can be performed [7]. Using this system, full-length post-translationally modified antibodies can be produced within hours, making the screening of orthogonal tRNAs, or synthetases, ncaa, antibody candidates, and ADCs rapid and straightforward [5].

In this chapter, we describe the proof-of-concept for the cellfree synthesis of antibodies containing ncaa. To allow for the sitespecific introduction of ncaa, the chosen model antibody contained an amber stop codon at amino acid position 134 in the $\mathrm{CHI}$ domain of antibody heavy chain (HC). In the first part, we expressed antibodies containing a Bodipy-TMR-lysine, pre-charged on a tRNA. Autoradiography and in-gel fluorescence analysis showed the expression of the fluorescently labeled antibody of interest. In the second part, we expressed antibodies containing p-azido-L-phenylalanine (AzF) by using an orthogonal system, composed of an engineered E. coli tRNA [8] amino-acylated by an engineered E. coli tyrosine synthetase [9]. Autoradiography confirmed the synthesis of suppression and full-length product. Subsequently, the fluorophore DyLight 650-phosphine was conjugated to the antibody by Staudinger ligation. The successful conjugation was shown by in-gel fluorescence. 


\section{Materials}

Prepare all buffers and solutions using ultrapure water.

\subsection{CFPS Using CHO Lysate}

1. Ice pan.

2. $1.5 \mathrm{~mL}$ reaction tubes.

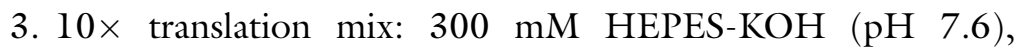
$2250 \mathrm{mM} \mathrm{KOAc}, 2.5 \mathrm{mM}$ spermidine, $1 \mathrm{mM}$ of each canonical amino acid, and $39 \mathrm{mM} \mathrm{Mg}(\mathrm{OAc})_{2}$. Store at $-80{ }^{\circ} \mathrm{C}$.

4. CHO lysate prepared as described previously $[10,11]$ ( see Note 1). Shock-freeze in liquid nitrogen after every usage and store at $-80{ }^{\circ} \mathrm{C}$.

5. T7 RNA polymerase.

6. $5 \times$ energy mix: $100 \mathrm{mM}$ creatine phosphate, $1.5 \mathrm{mM}$ GTP, $1.5 \mathrm{mM}$ CTP, $1.5 \mathrm{mM}$ UTP, $8.75 \mathrm{mM}$ ATP. and $0.5 \mathrm{mM} \mathrm{m}^{7} \mathrm{G}$ (ppp)G cap analog. Store at $-80^{\circ} \mathrm{C}$.

7. ${ }^{14} \mathrm{C}$-leucine $(200 \mathrm{dpm} / \mathrm{pmol}, 100 \mathrm{dpm} / \mathrm{pmol})$. Store at $-20{ }^{\circ} \mathrm{C}$.

8. Plasmid encoding antibody HC, plasmid encoding antibody light chain (LC) (Fig. 1) (see Note 2). Store at $-20^{\circ} \mathrm{C}$.

9. Ultrapure water.

10. Thermomixer.

11. Phosphate-buffered saline (PBS) containing $0.2 \% n$-Dodecyl $\beta$-D-maltoside (DDM). Store at $4{ }^{\circ} \mathrm{C}$.

1. Ice pan.

2. $1.5 \mathrm{~mL}$ reaction tubes.

3. DNA template encoding modified tyrosyl-tRNA-synthetase (eAzFRS, including the mutations Thr37, Ser182, Alal83, and Arg265 [9] and a C-terminal Strep-Tag) from E. coli, cloned into a vector containing a T7 promotor. We used the vector $\mathrm{pQE} 2$ vector ( $\mathrm{pQE} 2$-eAzFRS-SII) (see Note 3).

4. E. coli expression system (RTS 500 E. coli HY Kit, Biotechrabbit).

5. Thermomixer with RTS 500 thermomixer adapter.

6. $100 \mathrm{mM}$ Isopropyl $\beta$-D-1-thiogalactopyranoside (IPTG).

7. Gravity flow Strep-Tactin ${ }^{\circledR}$ superflow mini-column $(0.2 \mathrm{~mL})$.

8. Strep-Tactin ${ }^{\circledR}$ Purification Buffer Set: $10 \times$ Washing Buffer (1 M Tris-Cl, $\mathrm{pH}$ 8.0, 1.5 M NaCl, $10 \mathrm{mM}$ EDTA), $10 \times$ Elution Buffer ( $1 \mathrm{M}$ Tris-Cl, $\mathrm{pH} 8.0,1.5 \mathrm{M} \mathrm{NaCl}, 10 \mathrm{mM}$ EDTA, $25 \mathrm{mM}$ Desthiobiotin) and $10 \times$ Regeneration Buffer 
a

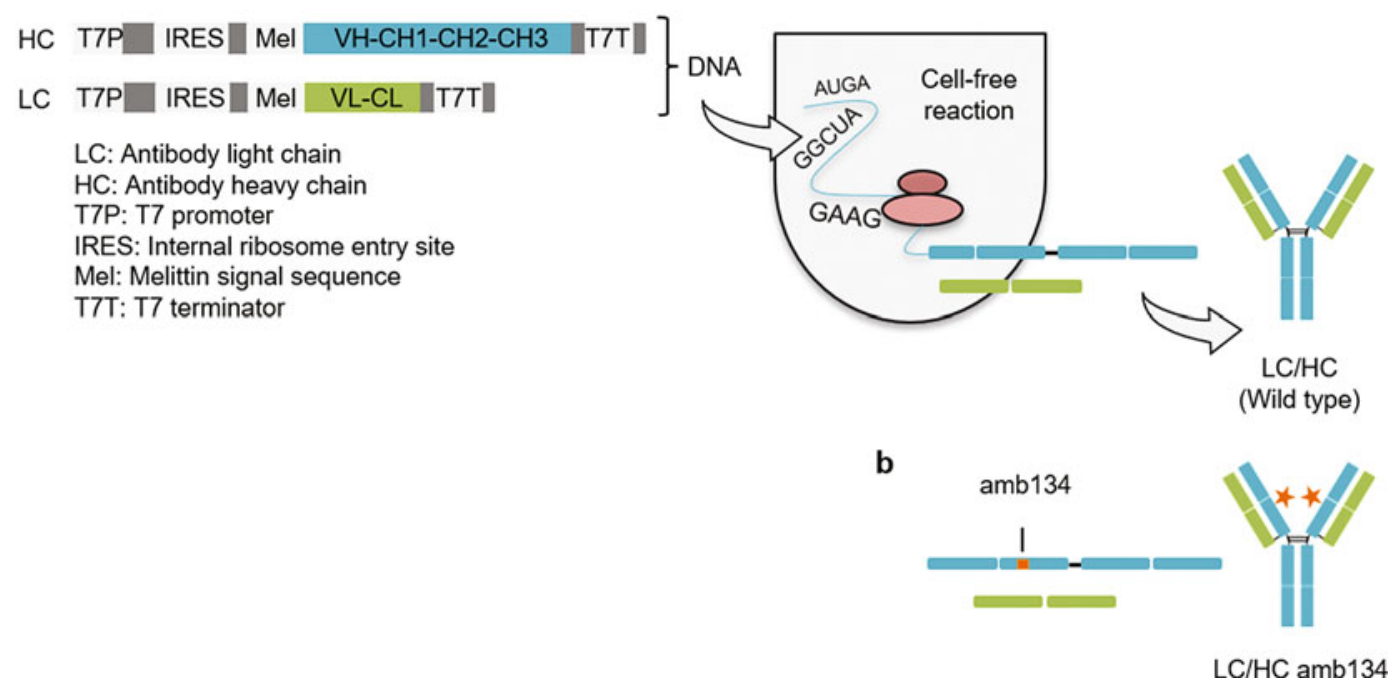

Fig. 1 Schematic presentation of the template design of antibody heavy (HC) and light chain (LC) and their rapid cell-free synthesis and assembly to functional IgG. (a) Template design without amber (amb) stop codon. (b) Template design with amber stop codon to allow for the site-specific incorporation of a ncaa into cell-free synthesized antibody HC. The amb stop codon TAG was positioned in the $\mathrm{CH} 1$ domain (replacing S134, EU numbering) of $\mathrm{HC}$. Orange asterisks indicate fluorescent dye conjugated to the incorporated ncaa.

\subsection{Preparation of Orthogonal tRNA}

2.3.1 PCR Amplification of the TRNA Gene
(1 M Tris-Cl, $1.5 \mathrm{M} \mathrm{NaCl}, 10 \mathrm{mM}$ EDTA, $10 \mathrm{mM}$ HABA (hydroxyl-azophenyl-benzoic acid)).

9. Zeba ${ }^{\text {TM }}$ Spin Desalting Columns (7 K MWCO, $0.5 \mathrm{~mL}$ ).

10. Amicon ${ }^{\circledR}$ Ultra Centrifugal Filters $(10 \mathrm{~K}$ device, $0.5 \mathrm{~mL}$ ).

11. Synthetase storage buffer: $50 \mathrm{mM}$ HEPES pH 7.6, $10 \mathrm{mM}$ KOAc, $1 \mathrm{mM} \mathrm{MgCl} 2,4 \mathrm{mM}$ DTT.

12. NanoDrop 2000c.

1. Vector containing the nucleotide sequence of tRNATyrCUA (SupF Gene).

2. tRNATyrCUA-specific forward primer $\left(5^{\prime} \mathrm{CgA}\right.$ gCT $\mathrm{CgC}$ CCA CCg gAA TTC $3^{\prime}$ ) and $2^{\prime}$-OMe reverse primer ( $5^{\prime} \mathrm{Tgg}$ Tgg Tgg ggg AAg gAT TCg $3^{\prime}$ ).

3. $0.2 \mathrm{~mL}$ PCR tubes.

4. PCR cycler.

5. Taq DNA polymerase.

6. Taq buffer.

7. dNTPs.

8. $25 \mathrm{mM} \mathrm{MgCl}_{2}$.

9. Agarose gel electrophoresis chamber. 
2.3.2 Transcription, Isolation, and Folding of $t R N A$

2.4 Site-Specific Incorporation of Non-canonical Amino Acids

\subsection{Qualitative Protein Analysis}

10. Agarose.

11. Rotiphorese $10 \times$ TBE buffer.

12. DNA stain.

13. DNA ladder.

14. PCR Purification Kit.

1. $5 \times$ transcription buffer: $400 \mathrm{mM}$ HEPES-KOH, $0.5 \mathrm{mM}$ spermidine, $50 \mathrm{mM}$ DTE and $75 \mathrm{mM} \mathrm{MgCl}_{2}$.

2. $5 \times$ NTP mix containing $18.75 \mathrm{mM}$ ATP, $18.75 \mathrm{mM}$ CTP, $18.75 \mathrm{mM}$ UTP, and $7.5 \mathrm{mM}$ GTP.

3. T7 RNA Polymerase.

4. DNaseI ( 1 U per $\mu$ g plasmid DNA).

5. $10 \times$ MOPS buffer: $200 \mathrm{mM}$ MOPS, $50 \mathrm{mM} \mathrm{NaOAc}, 10 \mathrm{mM}$ EDTA, pH 8.0.

6. MOPS sample buffer: $8 \%(\mathrm{v} / \mathrm{v})$ formaldehyde, $12 \mathrm{~mL}$ formamide, $2.4 \mathrm{~mL} 10 \times$ MOPS buffer, $0.05 \%(\mathrm{v} / \mathrm{v})$ bromophenol blue to a total volume of $24 \mathrm{~mL}$.

7. TRIzol reagent.

8. High Performance Liquid Chromatography (HPLC) grade Chloroform.

9. HPLC grade isopropanol.

10. $75 \%$ ethanol.

11. Cooled centrifuge.

12. NanoDrop 2000c.

13. PCR cycler.

1. $100 \mu \mathrm{M}$ Bodipy-TMR-lysine-tRNACUA (Biotechrabbit). Store at $-80{ }^{\circ} \mathrm{C}$.

2. $100 \mu \mathrm{M}$ eAzFRS. Store at $-80{ }^{\circ} \mathrm{C}$.

3. $100 \mu \mathrm{M}$ tRNATyrCUA. Store at $-80{ }^{\circ} \mathrm{C}$.

4. $100 \mathrm{mM} \mathrm{AzF}$ (Bachem AG; Bubendorf, Schweiz). Store at $-80{ }^{\circ} \mathrm{C}$.

5. Phosphate-buffered saline (PBS). Store at $4{ }^{\circ} \mathrm{C}$.

6. PBS containing $0.2 \%$ DDM. Store at $4{ }^{\circ} \mathrm{C}$.

1. SDS-PAGE sample buffer: $1 \times$ LDS buffer containing $106 \mathrm{mM}$ Tris $\mathrm{HCl}, 141 \mathrm{mM}$ Tris base, $2 \%$ LDS, $10 \%$ glycerol, $0.51 \mathrm{mM}$ EDTA, $0.22 \mathrm{mM}$ SERVA Blue G, $0.175 \mathrm{mM}$ Phenol Red, $\mathrm{pH} 8.5$.

2. $3-8 \%$ Tris acetate gels. 
3. Fluorescently labeled protein ladder for SDS-PAGE.

4. SDS-PAGE running buffer: $50 \mathrm{mM}$ MES, $50 \mathrm{mM}$ Tris Base, $0.1 \%$ SDS, 1 mM EDTA, pH 7.3.

5. SDS-PAGE gel tank system.

6. Radioactive ink.

7. Acetone.

8. Water bath.

9. Fluorescence/phosphorimager.

10. Gel dryer.

11. Phosphor screens.

\section{Methods}

\subsection{Cell-free Synthesis and Fluorescence Labeling of IgG Using Pre-Charged tRNA}

3.1.1 Batch-Based CFPS
Batch-based cell-free reactions are carried out as coupled transcription-translation reaction, in which transcription and translation take place simultaneously in the same reaction compartment ("one-pot").

1. Thaw all components of the cell-free reaction on ice. Mix all components thoroughly before usage. Protect pre-charged tRNA Bodipy-TMR-lysine-tRNACUA from light ( see Note 4).

2. Pipet the following components on ice using a $1.5 \mathrm{~mL}$ reaction vessel: $5 \mu \mathrm{L} 10 \times$ translation mix (f.c. $1 \times$ ), $20 \mu \mathrm{L}$ CHO lysate (f.c. $40 \%$ ), $1 \mu \mathrm{L}$ T7 RNA polymerase (f.c. $1 \mathrm{U} / \mu \mathrm{L}$ ), and $10 \mu \mathrm{L}$ $5 \times$ energy mix (f.c. $1 \times$ ). Mix thoroughly after addition of each component (see Note 5 ).

3. Add $2.5 \mu \mathrm{L}$ of $200 \mathrm{dpm} / \mathrm{pmol}^{14} \mathrm{C}$-leucine (specific radioactivity of $66.67 \mathrm{dpm} / \mathrm{pmol}$ f.c.) for subsequent qualitative analysis by autoradiography.

4. For fluorescence labeling, supplement the cell-free reaction with $2 \mu \mathrm{M}$ Bodipy-TMR-lysine-tRNACUA. Protect the translation mixture from light during pipetting and incubation.

5. Add HC and LC encoding plasmid at a final concentration of $60 \mathrm{nM}$ each (see Note 6).

6. Adjust the final volume of the reaction mix with ultrapure water to $50 \mu \mathrm{L}$ ( see Note 7$)$.

7. Mix all components thoroughly and incubate the reaction at $27^{\circ} \mathrm{C}$ and $500 \mathrm{rpm}$ for $3 \mathrm{~h}$ in a thermomixer ( $\mathrm{see}$ Note 8). After completing the cell-free reaction place reaction vessels on ice and proceed with the procedure described in Subheadings 3.2 and 3.4 (Fig. 2). 


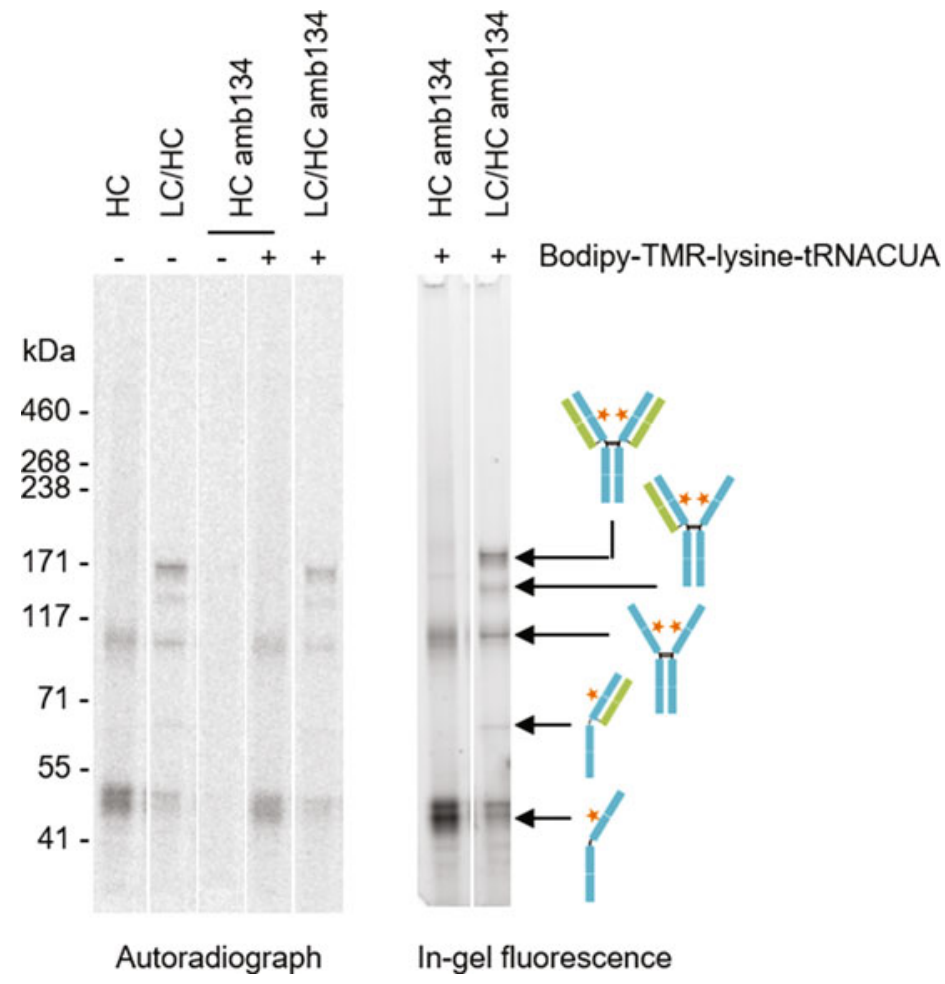

Fig. 2 Batch-based cell-free synthesis and site-specific fluorescence labeling of antibodies with Bodipy-TMR-lysine-tRNACUA by amber (amb) suppression. Qualitative analysis of cell-free synthesized antibody heavy chain ( $\mathrm{HC}$ ) and light chain (LC) was performed by SDS-Page followed by autoradiography (left side) and in-gel fluorescence (right side) (analysis of MF). Cell-free synthesis was performed in the presence of ${ }^{14} \mathrm{C}$-leucine and in the presence $(+)$ or absence (-) of Bodipy-TMR-lysine-tRNACUA. The amb stop codon TAG was positioned in the $\mathrm{CH} 1$ domain (replacing S134, EU numbering) of HC. Orange asterisks indicate fluorescent dye conjugated to the incorporated ncaa. Unassembled LC (25.4 kDa) and termination product of $\mathrm{HC}$ amb134 (16.4 kDa) cannot be visualized in the autoradiograph because of its low molecular weight

3.2 Fractionation of Translation Mixtures
1. Centrifuge translation mixtures at $16,000 \times \mathrm{g}$ for $10 \mathrm{~min}$ at $4{ }^{\circ} \mathrm{C}$. Take off the supernatant $(\mathrm{SNl})$ and discard.

2. Carefully resuspend the microsomal pellet in PBS supplemented with $0.2 \%$ DDM by pipetting up and down for several times. Incubate the solution for $45 \mathrm{~min}$ at room temperature (RT) under intense agitation (see Note 9).

3. Centrifuge the solution at $16,000 \times \mathrm{g}$ for $10 \mathrm{~min}$ at $4{ }^{\circ} \mathrm{C}$ to separate soluble antibodies, located in the supernatant (supernatant 2, SN2), from the microsomes. Take off the supernatant (containing soluble antibodies) and place it on ice. Analyze cell-free synthesized antibodies as described in Subheading 3.4. 


\subsection{Cell-free Synthesis and Fluorescence Labeling of IgG Using Orthogonal System}

3.3.1 Preparation

of Orthogonal Synthetase
1. Enhanced tRNA synthetase is produced using the E. coli-based CECF-system "RTS500 ProteoMaster E. coli HY Kit."

2. First, reconstitute the buffers and the E. coli lysate in reconstitution buffer according to the manufacturer's instructions. Pipet everything on ice and mix the buffers and solutions thoroughly.

3. Prepare the reaction mixture as follows: Pipet $525 \mu \mathrm{L} \mathrm{E}$. coli lysate, $225 \mu \mathrm{L}$ reaction mix, $270 \mu \mathrm{L}$ amino acid mix without methionine, $30 \mu \mathrm{L}$ methionine, $11 \mu \mathrm{L}$ IPTG and $39 \mu \mathrm{L}$ template pQE2-eAzFRS-SII containing $110 \mu \mathrm{g}$ plasmid DNA, and mix the solution thoroughly.

4. For the feeding mixture, pipet $7990 \mu \mathrm{L}$ feeding mix, $110 \mu \mathrm{L}$ IPTG, $2650 \mu \mathrm{L}$ amino acid mix without methionine, and $300 \mu \mathrm{L}$ methionine. Mix the solution thoroughly.

5. Fill the reaction chamber (red lid) with the complete volume of reaction mix and the feeding chamber (colorless lid) with the complete volume of feeding mix. Insert the chamber into the RTS 500 adapter in a thermomixer. Incubate the reaction at $30{ }^{\circ} \mathrm{C}$ for $24 \mathrm{~h}$ at $1000 \mathrm{rpm}$. Harvest the reaction mix from the reaction chamber and place the reaction mixture on ice.

6. In order to separate soluble from insoluble protein, centrifuge the translation mix at $16,000 \times \mathrm{g}$ for $10 \mathrm{~min}$ at $4{ }^{\circ} \mathrm{C}$. Harvest the supernatant containing soluble eAzFRS by pipetting.

7. Subsequently, eAzFRS is purified via its C-terminal Strep-Tag. Purification is performed using Strep-Tactin Gravity Flow Columns $(200 \mu \mathrm{L})$.

8. Equilibrate each column with $2 \times 800 \mu \mathrm{L}$ washing buffer and add $500 \mu \mathrm{L}$ of the supernatant from this step to each column.

9. Once the supernatant has completely entered the column, wash each column $5 \times$ with $200 \mu \mathrm{L}$ washing buffer (see Note 10).

10. To elute the synthetase, add $6 \times 100 \mu \mathrm{L}$ elution buffer to each column. Collect each flow-through and analyze separately. Afterwards, pool all fractions containing the target protein.

11. To regenerate the column, add $3 \times 1 \mathrm{~mL}$ regeneration buffer to each column, followed by addition of $2 \times 800 \mu \mathrm{L}$ of $1 \times$ washing buffer. For storage add $2 \mathrm{~mL}$ washing buffer and place the columns at $4{ }^{\circ} \mathrm{C}$.

12. To exchange the elution buffer to synthetase storage buffer, apply pooled elution fractions to Zeba ${ }^{\mathrm{TM}}$ Spin Desalting Columns. First, remove the storage solution of the Zeba ${ }^{\mathrm{TM}}$ Spin Desalting Column by centrifugation of the column at $1500 \times \mathrm{g}$ for $1 \mathrm{~min}$. Subsequently, add $300 \mu \mathrm{L}$ synthetase storage buffer to the resin bed and centrifuge the column at $1500 \times \mathrm{g}$ for $1 \mathrm{~min}$. After repeating this step $2 \times$ place the 
3.3.2 Preparation

of Orthogonal tRNA column into a new collection tube and apply $100 \mu \mathrm{L}$ of the pooled synthetase solution to each column. Collect target proteins by a final centrifugation step at $2000 \times \mathrm{g}$ for $2 \mathrm{~min}$.

13. Concentrate target protein by using Amicon Centrifugal Filter Devices $0.5 \mathrm{~mL}$. Adjust the volume of the synthetase from step 12 to $500 \mu \mathrm{L}$ with storage buffer and add this solution to the concentrator. Centrifuge at $14,000 \times \mathrm{g}$ for $10 \mathrm{~min}$ and $4{ }^{\circ} \mathrm{C}$. Collect the flow-through. The concentration of the flowthough can be determined by photometric measurement using NanoDrop based on the calculated molecular mass of the synthetase $(48.6 \mathrm{kDa})$ and the extinction coefficient $(54.3)$ (see Note 11). Store synthetase at $-80^{\circ} \mathrm{C}$ after shock freezing in liquid nitrogen.

1. First, suitable DNA templates of the tRNA gene need to be generated. For this, a reverse primer containing a 2'-OMe group has to be used in order to prevent unspecific addition of nucleotides to the $3^{\prime}$ end by the T7 RNA polymerase.

2. The PCR reaction is composed of the following components: $1 \times$ Taq Buffer, $0.2 \mathrm{mM}$ dNTP mix, $0.5 \mu \mathrm{M}$ forward primer, $0.5 \mu \mathrm{M}$ reverse primer, $2.5 \mathrm{mM} \mathrm{MgCl}_{2}, 0.01 \mathrm{ng} / \mu \mathrm{L}$ plasmid, and $0.04 \mathrm{U} / \mu \mathrm{L}$ Taq DNA polymerase.

3 . Fill the reaction with ultrapure water to a final volume of $250 \mu \mathrm{L}$.

4. Use the following PCR program: (1) $5 \mathrm{~min} 95^{\circ} \mathrm{C}$, (2) $30 \mathrm{~s}$ $95{ }^{\circ} \mathrm{C}$, (3) $30 \mathrm{~s} 52{ }^{\circ} \mathrm{C}$, (4) $10 \mathrm{~s} 72{ }^{\circ} \mathrm{C}$, (5) $10 \mathrm{~min} 72{ }^{\circ} \mathrm{C}$, (6) cooling to $4{ }^{\circ} \mathrm{C}$. Repeat steps 2-4 30×. Analyze generated PCR products by agarose gel electrophoresis on a $2 \%$ agarose gel.

5. Purify amplified tRNA PCR products by using a PCR Purification Kit (see Note 12).

6. Apply $50 \mu \mathrm{L}$ PCR product per column.

7. Elute in $20 \mu \mathrm{L}$ ultrapure water.

8. Analyze DNA concentration using NanoDrop.

9. Thaw in vitro transcription components on ice. Mix all components before using.

10. Pipet the reactions at RT. The transcription reaction is composed of the following components: $100 \mu \mathrm{L} 5 \times$ transcription buffer (f.c. $1 \times$ ), $100 \mu \mathrm{L} 5 \times$ NTP mix (f.c. $\mathrm{l} \times$ ), $25 \mu \mathrm{L} 20 \times$ enzyme mix (f.c. $1 \times$ ), and $8 \mathrm{ng} / \mu \mathrm{L}$ (f.c.) template DNA. Fill the reaction with water to the final volume of $500 \mu \mathrm{L}$ ( see Note 13). Incubate the reaction for $3-6 \mathrm{~h}$ at $37^{\circ} \mathrm{C}$ and $500 \mathrm{rpm}$.

11. After completing the reaction, centrifuge tRNA transcripts at $12,000 \times \mathrm{g}$ for $1 \mathrm{~min}$ and collect the supernatant. 
3.3.3 Cell-free Synthesis of $\lg G$ and Site-Specific Incorporation of Non-canonical Amino Acids (Ncaa)
12. Analyze tRNA transcripts by agarose gel electrophoresis $(2 \%)$ using $2 \mu \mathrm{L}$ of the tRNA transcript (see Note 14).

13. Treat the transcription reaction with $1 \mathrm{U}$ DNaseI per $1 \mu \mathrm{g}$ plasmid DNA for $10 \mathrm{~min}$ at $37^{\circ} \mathrm{C}$ and $500 \mathrm{rpm}$.

14. Add a three-fold volume of TRIzol to the transcription reaction and mix carefully. TRIzol and chloroform shall be handled with care and under the fume hood. Incubate for $5 \mathrm{~min}$ at RT.

15. Add chloroform $(200 \mu \mathrm{L}$ per $1 \mathrm{~mL}$ TRIzol $)$ and mix for $15 \mathrm{~s}$ by carefully inverting the tube. Incubate $2-3 \mathrm{~min}$ at RT. Centrifuge at $12,000 \times \mathrm{g}, 4^{\circ} \mathrm{C}$ and $15 \mathrm{~min}$.

16. Remove the aqueous phase and transfer to a fresh reaction tube ( see Note 15).

17. Add isopropanol (HPLC grade, $500 \mu \mathrm{L}$ per $1 \mathrm{~mL}$ TRIzol) and mix carefully, followed by incubation over night at $4{ }^{\circ} \mathrm{C}$.

18. Centrifuge at $15,000 \times \mathrm{g}, 4^{\circ} \mathrm{C}$ for a minimum of $1 \mathrm{~h}$. Remove the supernatant and discard it.

19. Overlay the RNA pellet with ethanol ( $1 \mathrm{~mL} 75 \%$ per $1 \mathrm{~mL}$ TRIzol) and incubate at $-20{ }^{\circ} \mathrm{C}$ for $30 \mathrm{~min}$.

20. Centrifuge at $7.500 \times \mathrm{g}, 4^{\circ} \mathrm{C}$ for $10 \mathrm{~min}$. Remove the supernatant quantitatively and air dry the pellet.

21. Resuspend the pellet in water $(80 \mu \mathrm{L}$ per $0.5 \mathrm{~mL}$ transcription reaction).

22. Measure RNA concentration using NanoDrop and dilute to $100 \mu \mathrm{M}$.

23. To fold the RNA, use the following PCR program: $120 \mathrm{~s}$ $80{ }^{\circ} \mathrm{C}, 30$ s $75{ }^{\circ} \mathrm{C}, 30$ s $70{ }^{\circ} \mathrm{C}, 30$ s $65{ }^{\circ} \mathrm{C}, 30 \mathrm{~s} 60{ }^{\circ} \mathrm{C}, 30 \mathrm{~s}$ $55^{\circ} \mathrm{C}, 30 \mathrm{~s} 50{ }^{\circ} \mathrm{C}, 30 \mathrm{~s} 45^{\circ} \mathrm{C}, 30 \mathrm{~s} 40{ }^{\circ} \mathrm{C}, 30 \mathrm{~s} 35^{\circ} \mathrm{C}, 300 \mathrm{~s}$ $25{ }^{\circ} \mathrm{C}, 4{ }^{\circ} \mathrm{C}$.

24. Shock-freeze tRNA in liquid nitrogen and store at $-80^{\circ} \mathrm{C}$.

1. For the site-specific incorporation of ncaa into de novo synthesized antibodies cell-free reactions as described in Chap. 3, Subheading 1.1 need to be additionally supplemented with an orthogonal tRNA/synthetase pair and the non-canonical amino acids (ncaa).

2. Pipet the components in the following order and mix after addition of each component: $5 \mu \mathrm{L} 10 \times$ translation mix (f.c. $1 \times$ ), $1.5 \mu \mathrm{L} \mathrm{AzF}$ (f.c. $3 \mathrm{mM}$ ), $20 \mu \mathrm{L}$ CHO lysate (f.c. $40 \%$ ), $2.5 \mu \mathrm{L}$ tRNATyrCUA (f.c. $5 \mu \mathrm{M}$ ), $1.5 \mu \mathrm{L}$ eAzFRS (f.c. $3 \mu \mathrm{M}$ ), $2.5 \mu \mathrm{L}$ of $200 \mathrm{dpm} / \mathrm{pmol}{ }^{14} \mathrm{C}$-leucine (specific radioactivity of $66.67 \mathrm{dpm} / \mathrm{pmol}$ f.c.), $1 \mu \mathrm{L}$ T7 RNA polymerase (f.c. $1 \mathrm{U} / \mu \mathrm{L})$, and $10 \mu \mathrm{L} 5 \times$ energy mix $($ f.c. $1 \times)($ see Note 16). 
3.3.4 Labeling of IgG with Fluorescent Dye (Staudinger Ligation)

\subsection{Qualitative Protein Analysis}

3.4.1 SDS-PAGE and Autoradiography

3.4.2 In-Gel Fluorescence Analysis and Autoradiography
3. Add HC and LC encoding plasmid at a final concentration of $60 \mathrm{nM}$ each.

4. Adjust the final volume of the reaction mix with ultrapure water to $50 \mu \mathrm{L}$. Incubate the reaction for $3 \mathrm{~h}$ at $27^{\circ} \mathrm{C}$ and $500 \mathrm{rpm}$ and protect the reaction from light during incubation.

5. After completing the reaction, centrifuge the translation mixture at $16,000 \times \mathrm{g}$ for $10 \mathrm{~min}$ at $4{ }^{\circ} \mathrm{C}$. Remove and discard the resulting supernatant $(\mathrm{SNl})$.

6. Wash the microsomal fraction (MF) with $200 \mu \mathrm{L}$ PBS, centrifuge for $3 \mathrm{~min}$ at $16,000 \times \mathrm{g}$ at $4{ }^{\circ} \mathrm{C}$, remove the supernatant and resuspend the pellet in PBS including 0.2\% DDM. Incubate this solution for $45 \mathrm{~min}$ at RT under agitation.

7. Centrifuge for $10 \mathrm{~min}, 16,000 \times \mathrm{g}$ and $4{ }^{\circ} \mathrm{C}$. Remove the resulting supernatant $(\mathrm{SN} 2)$ which contains solubilized antibodies and place it on ice.

1. Pipet the following components: $5 \mu \mathrm{L}$ SN2 fraction, $1 \mu \mathrm{L}$ DyLight 650-phosphine (f.c. $10 \mu \mathrm{M}$ ), $4 \mu \mathrm{L}$ ultrapure water, resulting in $10 \mu \mathrm{L}$ final reaction volume. Incubate reactions for $\mathrm{l} \mathrm{h}$ at $25^{\circ} \mathrm{C}$ und $600 \mathrm{rpm}$.

2. Analyze labeling reaction by autoradiography and in-gel fluorescence as described in Chap. 3, Subheading 4. (Fig. 3).

1. Take a $6 \mu \mathrm{L}$ aliquot of the sample (e.g., TM, MF, SN2) and mix with $6 \mu \mathrm{L} 2 \times$ non-reducing LDS sample buffer. Incubate on a shaker for $15 \mathrm{~min}$ at RT (see Note 17).

2. Use $3-8 \%$ Tris acetate gels for gel electrophoresis. Pipet $12 \mu \mathrm{L}$ per gel pocket and run electrophoresis at $150 \mathrm{~V}$ for $1 \mathrm{~h}$.

3. After electrophoresis, remove the gel from the plastic cassette and put in $100 \mathrm{~mL}$ water for in-gel fluorescence analysis (3.4.2).

1. Analyze the gel using Amersham Typhoon RGB Biomolecular Imager. Place the gel onto the scanning surface and scan using the following parameters: $633 \mathrm{~nm}$ extinction and $670 \mathrm{~nm}$ emission for DyLight-phosphine and $532 \mathrm{~nm}$ extinction and $580 \mathrm{~nm}$ emission for Bodipy-TMR-lysine.

2. Rinse the gel three times with deionized water to remove SDS and buffer salts.

3. Dry gels for $90 \mathrm{~min}$ at $70{ }^{\circ} \mathrm{C}$ using a vacuum filtration system.

4. Label the marker bands of the dried gel with radioactive ink.

5. Place dried gel into a phosphorimager cassette and incubate for at least 3 days. 

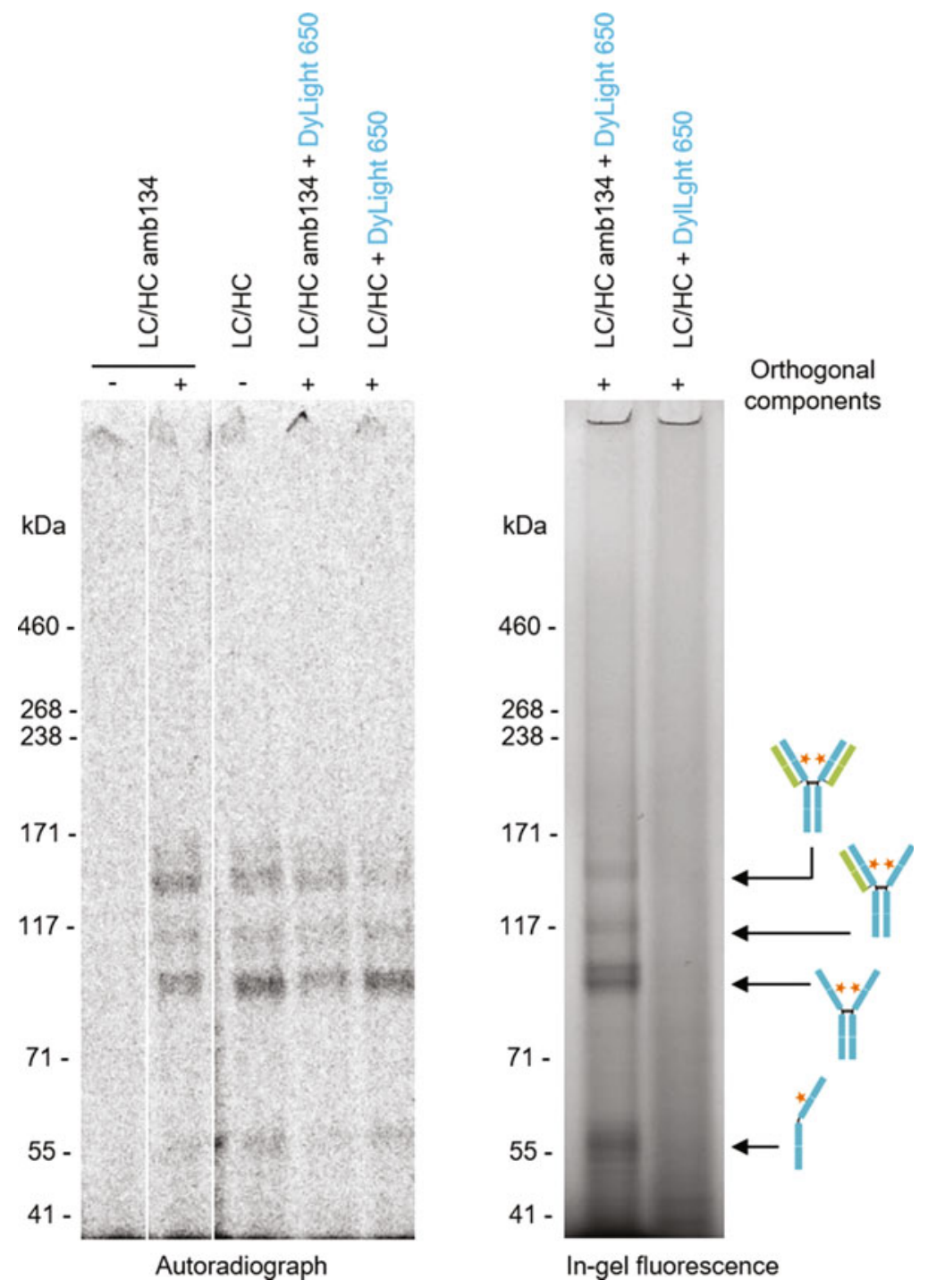

Fig. 3 Batch-based cell-free synthesis, site-specific introduction of ncaa by amber (amb) suppression and subsequent fluorescence labeling of antibodies with DyLight 650-phosphine. Qualitative analysis of cell-free synthesized antibody heavy chain ( $\mathrm{HC}$ ) and light chain (LC) was performed by SDS-Page followed by autoradiography (left side) and in-gel fluorescence (right side) (analysis of SN2). Cell-free synthesis was performed in the presence of ${ }^{14} \mathrm{C}$-leucine and with $(+)$ or without $(-)$ supplementation of orthogonal components (synthetase eAzPheRS-SII, tRNATyrCUA and ncaa p-azido-L-phenyalanine (AzF)). The amb stop codon TAG was positioned in the $\mathrm{CH} 1$ domain (replacing S134, EU numbering) of $\mathrm{HC}$. Orange asterisks indicate fluorescent dye conjugated to the incorporated ncaa. Unassembled LC (25.4 kDa) and termination product of HC amb134 (16.4 kDa) cannot be visualized in the autoradiograph because of its low molecular weight 
6. Scan the screens using the Typhoon Trio + Variable Mode Imager or Amersham Typhoon RGB Biomolecular Imager.

1. CHO lysates were prepared as described previously [10]. In brief, CHO cells were grown in a Biostat B-DCU II bioreactor (Sartorius Stedium Biotech $\mathrm{GmbH}$ ) at $37^{\circ} \mathrm{C}$ using a chemically defined and serum-free cell medium. Cells were grown to a density of $3.5-5 \times 10^{6}$ cells $/ \mathrm{mL}$ and harvested by centrifugation at $200 \times \mathrm{g}$ for $5 \mathrm{~min}$. Cells were washed twice and resuspended in a HEPES-based homogenization buffer (40 mM HEPES-KOH (pH 7.5), $100 \mathrm{mM} \mathrm{NaOAc}$ and $4 \mathrm{mM}$ DTT). Resuspended CHO cells were lysed mechanically by applying a 20-gauge needle and a syringe. By using the syringe, cells were manually passed through the needle. After cell disruption, the homogenate was centrifuged at $6500 \times \mathrm{g}$ for $10 \mathrm{~min}$ to remove cell nuclei and debris. The resulting supernatant was applied to a Sephadex G-25 column which was equilibrated with homogenization buffer. Elution fractions with the highest RNA/protein ratios were pooled. In order to remove the endogenous mRNA, cell lysates were mixed with $\mathrm{S} 7$ micrococcal nuclease (f.c. $10 \mathrm{U} / \mathrm{mL}$ ) and $\mathrm{CaCl}_{2}$ (f.c. $1 \mathrm{mM}$ ) and incubated for $2 \mathrm{~min}$ at RT. Inactivation of micrococcal nuclease was achieved by the addition of EGTA (f.c. $6.7 \mathrm{mM}$ ). Afterwards, creatine kinase (f.c. $100 \mu \mathrm{g} / \mathrm{mL}$ ) was added to the lysate in order to ensure the regeneration of ATP out of creatine phosphate. Aliquots of the $\mathrm{CHO}$ lysate were immediately shock frozen in liquid nitrogen and subsequently stored at $-80^{\circ} \mathrm{C}$ until further usage.

2. Coding sequences of $\mathrm{HC}$ and LC should be $\mathrm{N}$-terminally fused to the melittin signal sequence to allow for the translocation of de novo synthesized polypeptide chains into the lumen of the microsomal vesicles [7]. Furthermore, HC and LC sequences should be fused to regulatory sequences necessary for CFPS (Fig. 1). The $5^{\prime}$ untranslated region ( $\left.5^{\prime} \mathrm{UTR}\right)$ of HC/LC templates contained a $\mathrm{T} 7$ promotor sequence and an internal ribosomal entry site (IRES from the intergenic region (IGR) of the Cricket paralysis virus (CrPV), (Genbank accession no. AF218039, nucleotides 6025-6216)) as regulatory sequences to allow for efficient transcription based on T7 RNA polymerase and factor-independent translation initiation, respectively. The 3'UTR contained a T7 terminator sequence and a multiple cloning site for subsequent cloning. HC/LC sequences were synthesized de novo by Geneart (Life technologies, Thermo Fisher) and cloned into pMA vector backbone. 
The sequence of the variable domains was kindly provided by the lab of Michael Hust et al. (Technische Universität Braunschweig) [12]. The position of the amber stop codon in the $\mathrm{CHl}$ domain at Serin 134 was chosen according to Zimmerman et al. (2014) [4].

3. The template used for protein synthesis should contain a T7 promotor, ribosomal binding site, and T7 terminator such as pIX3.0, pIVEX2.3d, and pIVEX2.4d vectors. Alternatively, a T5 promotor as contained in $\mathrm{PQE} 2$ vectors can be used.

4. The fluorescent dye Bodipy is susceptible to light. Protect it from light by using colored tubes or wrap the tubes with aluminum foil.

5. It is very important to work in an RNase-free environment and with RNase-free equipment. Use RNase-free filter tips for pipetting and RNase-free reaction vessels. Pipette the components in the listed order. Furthermore, it is recommended to avoid repeated freeze-thaw cycles of all components. After usage, shock-freeze the lysate in liquid nitrogen and store it at $-80{ }^{\circ} \mathrm{C}$.

6. The DNA template used for CFPS should contain a T7 promotor. We found that the applied DNA template concentration is a potential parameter for optimization because template concentration influences protein synthesis efficiency. Different DNA templates may have different optimum concentrations within the cell-free reaction. For the synthesis of the chosen model antibody, we found that a 1:1 plasmid ratio of $\mathrm{HC} / \mathrm{LC}$, each added at $60 \mathrm{nM}$, worked best.

7. Cell-free reactions are scalable. You can adjust the final volume of the reaction according to the requirements of your experiment.

8. In general, the optimal temperature of the $\mathrm{CHO}$ cell-free system is $30^{\circ} \mathrm{C}[11]$ but the optimal incubation temperature may be different for different proteins. For antibody synthesis, $27{ }^{\circ} \mathrm{C}$ was found to result in the highest yields of active antibodies.

9. Cell-free synthesized antibodies which have been translocated and trapped inside the lumen of the microsomes can be released by re-solubilization of the microsomal vesicles using PBS supplemented with $0.2 \%$ DDM. It is important to thoroughly resuspend the microsomes within the buffer in order to release translocated antibodies quantitatively.

10. We find that it is beneficial to collect all fractions throughout the purification, buffer exchange, and concentration procedure (e.g., flow-through, washing fractions, elution fractions). Aliquots of these solutions should be diluted in SDS-PAGE 
sample buffer and analyzed by SDS-PAGE in order to monitor the purity of the aminoacyl-tRNA-synthetase during the preparation procedure.

11. We recommend to concentrate the synthetase up to a concentration of $5 \mathrm{~g} / \mathrm{L}$ to ensure a minimal final concentration of $100 \mu \mathrm{M}$. If necessary, repeat the concentration step.

12. We purify the PCR product using QIAquick PCR Purification Kit and determine the concentration of the PCR product by using a NanoDrop 2000c. For further analysis, prepare a $1 \%$ $(\mathrm{w} / \mathrm{v})$ agarose gel and load $1 \mu \mathrm{L}$ of the PCR product. The expected band size is 123 bps.

13. It is important to work in an RNase-free environment. Use RNase-free filter tips and reaction vessels.

14. Prepare a $2 \%(\mathrm{w} / \mathrm{v})$ agarose gel. For sample preparation, mix $2 \mu \mathrm{L}$ of the RNA with $6 \mu \mathrm{L}$ MOPS sample buffer and load the sample to the agarose gel. Use an RNA ladder. The expected band size is around 200 bps.

15. After centrifugation, three phases will be visible: the aqueous phase on top with approximately $50 \%$ of the total volume containing the RNA; a middle interphase which is nearly invisible and below the red phenol/chloroform phase. Try to isolate only the aqueous phase.

16. Reactive groups of ncaa are often sensitive to light and might become instable upon light exposure. Thus, protect solutions from light by using colored tubes or wrap the tubes with aluminum foil.

17. The use of non-reducing sample buffer is important to maintain the disulfide bonds which connect the polypeptide chains of the antibodies. Heating of samples before gel electrophoresis is not necessary.

\section{Acknowledgments}

The authors would like to thank Prof. Dr. Michael Hust for providing the sequence of the antibody variable domains. Furthermore, we would like to thank Doreen Wüstenhagen and Dana Wenzel (Fraunhofer IZI-BB, Potsdam-Golm) for their excellent support regarding the preparation of the $\mathrm{CHO}$ lysates used in this study. This work is supported by the European Regional Development Fund (EFRE), the German Ministry of Education and Research (BMBF, No. 031B0078A), and the German Research Foundation (DFG Priority Programme 1623). 


\section{References}

1. KEGG DRUG Database. [Online] 15.02.2021. https://www.genome.jp/kegg/ drug/br08328.html

2. Davies SL, James DC (2009) Engineering mammalian cells for recombinant monoclonal antibody production. [Buchverf.] Mohamed Al-Rubeai. Cell line development. Springer Netherlands, Dordrecht. Bd. 6, S. 153-173

3. Axup JY (2012) Synthesis of site-specific antibody-drug conjugates using unnatural amino acids. Proc Natl Acad Sci USA 109:16101-16106

4. Feng T, Lu Y, Manibusan A et al (2014) A general approach to site-specific antibody drug conjugates. Proc Natl Acad Sci U S A 111:1766-1771

5. Zimmerman ES, Heibeck TH, Gill A et al (2014) Production of site-specific antibodydrug conjugates using optimized non-natural amino acids in a cell-free expression system. Bioconjug Chem 25:351-361

6. VanBrunt MP, Shanebeck K, Caldwell $\mathrm{Z}$ et al (2015) Genetically encoded Azide containing amino acid in mammalian cells enables sitespecific antibody-drug conjugates using click cycloaddition chemistry. Bioconjug Chem 26:2249-2260

7. Stech M, Nikolaeva O, Thoring L et al (2017) Cell-free synthesis of functional antibodies using a coupled in vitro transcriptiontranslation system based on $\mathrm{CHO}$ cell lysates. Sci Rep 7:S12030

8. Edwards H, Schimmel P (1990) A bacterial amber suppressor in Saccharomyces cerevisiae is selectively recognized by a bacterial aminoacyl-tRNA synthetase. Mol Cell Biol 10:1633-1641

9. Chin JW, Cropp TAS, Anderson JC et al (2003) An expanded eukaryotic genetic code. Science 301:964-967

10. Brödel AK, Wüstenhagen DA, Kubick S (2015) Cell-free protein synthesis systems derived from cultured mammalian cells. Methods Mol Biol (Clifton, NJ) 1261:129-140

11. Thoring L, Wüstenhagen DA, Borowiak M et al (2016) Cell-free systems based on CHO cell lysates: optimization strategies, synthesis of "difficult-to-express" proteins and future perspectives. PLoS One 11:e0163670

12. Thie H, Toleikis L, Li J et al (2011) Rise and fall of an anti-MUCl specific antibody. PLoS One 6:el5921

13. Thoring L, Dondapati SK, Stech $\mathrm{M}$ et al (2017) High-yield production of "difficult-toexpress" proteins in a continuous exchange cell-free system based on $\mathrm{CHO}$ cell lysates. Sci Rep 7:11710

Open Access This chapter is licensed under the terms of the Creative Commons Attribution 4.0 International License (http://creativecommons.org/licenses/by/4.0/), which permits use, sharing, adaptation, distribution and reproduction in any medium or format, as long as you give appropriate credit to the original author(s) and the source, provide a link to the Creative Commons license and indicate if changes were made.

The images or other third party material in this chapter are included in the chapter's Creative Commons license, unless indicated otherwise in a credit line to the material. If material is not included in the chapter's Creative Commons license and your intended use is not permitted by statutory regulation or exceeds the permitted use, you will need to obtain permission directly from the copyright holder. 